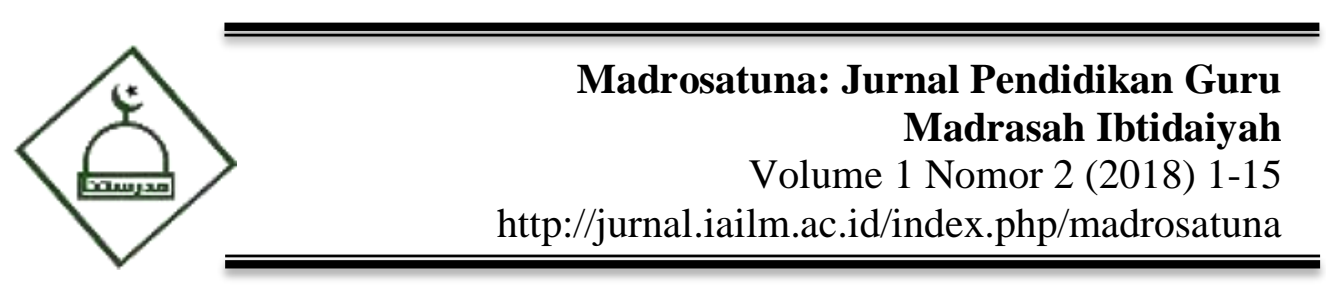

\title{
PENERAPAN MODEL PEMBELAJARAN KOOPERATIF \\ TIPE STAD(STUDENT TEAM ACHIEVEMENT DIVISIONS) UNTUK MENINGKATKAN HASIL BELAJAR PESERTA DIDIK DALAM PEMBELAJARAN IPA
}

\author{
Tita Suherni $^{1}$, Nurhamzah ${ }^{2}$, Nina Yarana Silmiati ${ }^{3}$ \\ IAILM Suryalaya \\ Titsu_dadsu@gmail.com
}

\begin{abstract}
Abstrak: Penerapan Model Pembelajaran Kooperatif Tipe STAD (Student Team Achievement Divisions) untuk Meningkatkan Hasil Belajar Peserta Didik dalam Pembelajaran IPA

Kurangnya guru dalam menerapkan model pembelajaran mengakibatkan rendahnya hasil belajar peserta didik khususnya pada mata pelajaran IPA. Guru lebih sering menggunakan model pembelajaran yang konvensional dan ceramah sehingga kurang memotivasi peserta didik. Permasalahan yang timbul apakah dengan menerapkan model pembelajaran kooperatif tipe STAD dapat meningkatkan hasil belajar peserta didik dalam pembelajaran IPA di kelas III MIS Hegarmanah?

Penelitian ini bertujuan untuk meningkatkan hasil belajar peserta didik pada mata pelajaran IPA dengan menggunakan model pembelajaran kooperatif tipe STAD (Student Team Achievement Divisions). Metode yang digunakan dalam penelitian tindakan ini adalah metode penelitian tindakan kelas yaitu suatu pengamatan yang menerapkan tindakan didalam kelas dengan menggunakan aturan sesuai dengan metodologi penelitian yang dilakukan dalam beberapa periode atau siklus.

Berdasarkan hasil pengolahan data diperoleh bahwa hasil belajar peserta didik pada mata pelajaran IPA mengalami peningkatkan yang cukup signifikan setelah menerapkan model pembelajaran kooperatif tipe STAD (Student Team Achievement Divisions). Hal ini ditunjukan adanya peningkatan nilai rata-rata kelas pada siklus I yaitu 62,69 dan mengalami peningkatan yang cukup signifikan pada siklus ke II menjadi 81,78. Selain itu ketuntasan belajar pada siklus I dengan presentase $46,18 \%$ dan mengalami peningkatan dengan mencapai presentase 100\%. Dengan demikian dapat dikatakan bahwa hasil belajar pada siklus II sudah memenuhi target. Dapat disimpulkan dengan menggunakan model pembelajaran kooperatif tipe STAD (Student Team Achievement Divisions) dapat meningkatkan hasil belajar peserta didik dalam mata pelajaran IPA kelas III di MIS Hegarmanah.
\end{abstract}

Kata kunci : Model Pembelajaran Kooperatif Tipe STAD (Student Team Achievement Divisions), Hasil Belajar, Pembelajaran IPA. 
Abstract: Applying Cooperative Learning Model Type STAD (Student Team Achievement Divisions) to improve the students learning outcomes in science learning IPA

The lack of teachers in the enforcement of the model learning results in low learning outcomes of students, especially in their subjects IPA.Teachers more often use a learning model that conventional and lectures so that less motivated learners the problems that arise is by applying cooperative learning model type STAD can improve the students learning outcomes in science learning in class III MIS Hegarmanah

This study aims to improve results learn learners on the study IPA by using a model of learning cooperative type STAD (student team achievement divisions). Methods used in the study this action is the research the class is a observation that implement action in the classroom with using the rules in accordance with the metodologi research conducted in some period or cycle.

Based on the results of data processing obtained that the learning outcomes of students on the subjects of IPA has increased significantly after applying cooperative learning model type STAD (student team achievement divisions). It is shown any increase in the value of the average grade in cycle I which 62,69 and has increased significantly in cycle II to 81,78 thuts it can be said that learning outcomes in cycle II already meet the target. It ca be concluded by using ccoperative learning model type STAD (student team achievement diivisions) can improve the students learning outcomes in the subjects science grade III MIS Hegarmanah.

Keyword : Cooperative learning model type STAD, learning outcomes, learning science

\section{Pendahuluan}

Ilmu Pengetahuan Alam (IPA) adalah sebuah mata pelajaran di SD/MI. IPA merupakan konsep pembelajaran alam dan mempunyai hubungan yang sangat luas terkait dengan kehidupan manusia. Pembelajaran IPA sangat berperan dalam proses pendidikan dan perkembangan teknologi. Pembelajaran IPA diharapkan dapat menjadi wahana bagi peserta didik untuk mempelajari diri sendiri dan alam sekitar, serta pengembangan lebih lanjut dalam penerapannya di kehidupan sehari-hari.

Peserta didik sebagai subjek pendidikan, dituntut supaya aktif dalam belajar mencari informasi dan mengeksplorasi sendiri atau secara kelompok. Guru hanya berperan sebagai fasilitator dan pembimbing ke arah pengoptimalan pencapaian ilmu pengetahuan yang dipelajari. Diharapkan dalam proses pembelajaran peserta didik mau dan mampu mengemukakan pendapat sesuai dengan apa yang telah dipahami, berinteraksi secara positif antara peserta didik dengan peserta didik, maupun antara peserta didik dengan guru apabila ada kesulitan.

Namun pada kenyataannya aktifitas yang ditunjukan peserta didik pada pembelajaran masih rendah seperti rendahnya minat peserta didik dalam belajar kelompok dimana pelaksanaan pembelajaran dilapangan melalui 


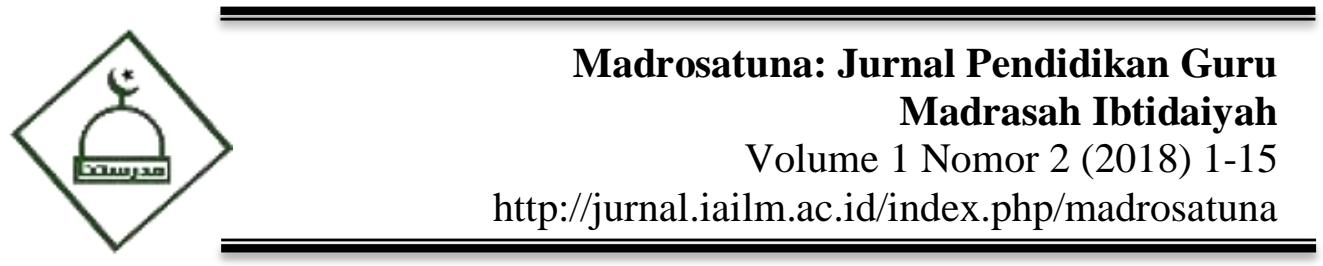

belajar kelompok masih jarang. Jika dilaksanakan, hasil yang di capai masih rendah. Pada umumnya peserta didik cenderung pasif, hanya menerima apa yang disampaikan guru tanpa bisa mengeluarkan pendapat, bertanya, serta menjawab pertanyaan. Jika guru mengajukan pertanyaan, peserta didik tidak berani menjawab, jika ada itu hanya 4-5 orang peserta didik saja. Dan jika ada kendala peserta didik tidak berani bertanya. Akibatnya nilai yang diperoleh peserta didik masih di bawah KKM, dimana KKM yang ditetapkan di MIS Hegarmanah khususnya pada mata pelajaran IPA di kelas 3 adalah 65 . Berdasarkan permasalahan di atas, maka upaya peningkatan hasil belajar peserta didik kelas III dalam pembelajaran IPA di MIS Hegarmanah merupakan masalah yang harus di tanggulangi. Salah satu cara yang dapat dijadikan alternatif untuk mengatasi permasalahan tersebut yaitu dengan penerapan model pembelajaran kooperatif.

Menurut Nurhamzah (2012:159), model pembelajaran kooperatif merupakan suatu model pembelajaran yang mengutamakan adanya kelompok. Setiap peserta didik yang ada dalam kelompok mempunyai tingkat kemampuan yang berbeda-beda (tingga, sedang, dan rendah)

Melalui model pembelajaran kooperatif ini di harapkan siswa dapat belajar lebih aktif dalam mengeluarkan pendapatnya dan suasana yang kondusif untuk mengembangkan pengetahuan, sikap, serta keterampilan sosial seperti keterampilan bekerja sama yang bermanfaat dalam kehidupan di masyarakat.

\section{Metode Penelitian}

Metode yang digunakan dalam penelitian ini adalah metode deskriptif dengan pendekatan kualitatif. Instrumen yang digunakan adalah observasi dan tes. Pengolahan dan analisis data bertujuan untuk mengolah data mentah berupa hasil penelitian agar dapat ditafsirkan dan mengandung makna. Penafsiran data tersebut antara lain untuk menjawab pertanyaan pada rumusan masalah. Teknik Analisis Hasil Observasi dalam teknik analisis observasi ini untuk mengolah data hasil dari Aktivitas siswa dan aktivitas guru serta untuk menjawab rumusan masalah, Teknik analisis datanya dilakukan dengan cara dihitung dan dipaparkan secara sederhana hasil analisis lembar observasi setiap siklus. Kemudian dirata-ratakan dan dipersentasikan kedalam grafik sederhana.

\section{Hasil Penelitian}

\section{Perencanaan}

\section{a. SIKLUS 1}

Perencanaan penelitian tindakan kelas diawali dengan mempersiapkan sumber serta bahan pembelajaran yang diperlukan pada penelitian tindakan kelas, antara lain buku sumber, alat praga, lembar observasi, instrumen penilaian dan bahan pembelajaran lainnya. Kegiatan lain dalam tahap perencanaan ini adalah peyusunan Rencana Pelaksanaan Pembelajaran (RPP). Skenario pembelajaran yang disusun dalam RPP merupakan langkah - langkah pembelajaran yang akan 
dilaksanakan dalam proses pembelajaran dan secara garis besar terbagi atas kegiatan awal, kegiatan inti dan kegiatan akhir.

Dalam pembelajaran siklus I terdiri dari dua tatap muka dengan SK dan KD yang sama, sedangkan indikator yang hendak dicapai untuk kedua tatap muka berbeda yaitu sebagai berikut :

Tabel 1. Hasil Penelitian Perencanaan Siklus I

\begin{tabular}{|c|c|c|c|}
\hline $\begin{array}{c}\text { Standar } \\
\text { Kompetensi }\end{array}$ & $\begin{array}{c}\text { Kompetensi } \\
\text { Dasar }\end{array}$ & Indikator & Waktu \\
\hline \multirow{3}{*}{$\begin{array}{l}\text { Memahami } \\
\text { berbagai cara } \\
\text { gerak benda, } \\
\text { hubungannya } \\
\text { dengan energi } \\
\text { dan sumber } \\
\text { energi. }\end{array}$} & \multirow{3}{*}{$\begin{array}{l}\text { Mendeskripsikan } \\
\text { hasil pengamatan } \\
\text { tentang pengaruh } \\
\text { energi panas, } \\
\text { gerak, dan bunyi } \\
\text { dalam kehidupan } \\
\text { sehari-hari }\end{array}$} & $\begin{array}{l}\text { Mengetahui } \\
\text { pengertian } \\
\text { energi }\end{array}$ & $\begin{array}{l}\text { Pertemuan } \\
\text { ke }-1 \\
\text { Sabtu,08 } \\
\text { septembber } \\
2018\end{array}$ \\
\hline & & $\begin{array}{l}\text { Menyebutkan } \\
\text { bentuk- } \\
\text { bentuk energi }\end{array}$ & $\begin{array}{l}\text { Pertemuan } \\
\text { ke }-1 \\
\text { Sabtu,08 } \\
\text { septembber } \\
2018\end{array}$ \\
\hline & & $\begin{array}{l}\text { Mengetahui } \\
\text { perubahan } \\
\text { bentuk energi }\end{array}$ & $\begin{array}{l}\text { Pertemuan } \\
\text { ke }-2 \\
\text { Senin,10 } \\
\text { septembber } \\
2018\end{array}$ \\
\hline
\end{tabular}

Sebelum pelaksanaan penelitian tindakan kelas, Rencana Pelaksanaan Pembelajaran yang telah disusun terlebih dahulu dinilai oleh observer dengan hasil sebagai berikut:

Tabel 2. Hasil Penilaian Penyusunan RPP Tindakan Siklus I

\begin{tabular}{|r|l|c|c|}
\hline No & \multicolumn{1}{|c|}{ Aspek Deskriptor } & Skor & Nilai \\
\hline 1 & $\begin{array}{l}\text { Aspek Standar Kompetensi (SK), Kompensi } \\
\text { Dasar (KD) dan Indikator Keberhasilan } \\
\text { Kompetensi }\end{array}$ & \multirow{2}{*}{3,66} \\
\hline & $\begin{array}{l}\text { a. Mencantumkan SK sesuai dengan mata } \\
\text { pelajaran yang diajarkan }\end{array}$ & 4 & 3 \\
\hline & $\begin{array}{l}\text { b. Mencantumkan satu KD berdasarkan SK } \\
\text { Cerumuskan indikator berdsarkan KD } \\
\text { sesuai materi ajar }\end{array}$ & $\begin{array}{l}\text { Perumusan dan penetapan tujuan } \\
\text { pembelajaran }\end{array}$ & 3,00 \\
\hline
\end{tabular}




\begin{tabular}{|c|c|c|c|}
\hline \multirow{4}{*}{ No } & Aspek Deskriptor & \multirow{2}{*}{$\begin{array}{c}\text { Skor } \\
4\end{array}$} & \multirow[t]{4}{*}{ Nilai } \\
\hline & $\begin{array}{l}\text { a. Tujuan tersusun berdasarkan SK, KD, } \\
\text { indikator percapaian kompetensi }\end{array}$ & & \\
\hline & $\begin{array}{l}\text { b. Tujuan tesusun secara sistematis sesuai } \\
\text { dengan hirearki materi pembelajaran }\end{array}$ & 3 & \\
\hline & $\begin{array}{l}\text { c. Tujuan menggunakan kata-kata } \\
\text { operasional sesuai karakteristik mata } \\
\text { pelajaran }\end{array}$ & 2 & \\
\hline \multirow[t]{4}{*}{3} & Pengembangan materi pembelajaran & & \multirow{4}{*}{2,66} \\
\hline & $\begin{array}{l}\text { a. Materi berdasarkan SK, KD, Indikator, } \\
\text { tujuan dan materi pembelajaran }\end{array}$ & 3 & \\
\hline & $\begin{array}{l}\text { b. Materi sesuai dengan minat, } \\
\text { perkembangan anak dan kebutuhan } \\
\text { belajar anak }\end{array}$ & 2 & \\
\hline & $\begin{array}{l}\text { c. Materi sesuai karakteristik dan kebutuhan } \\
\text { lingkungan sekolah }\end{array}$ & 3 & \\
\hline \multirow[t]{4}{*}{4} & Penetapan metode pembelajaran & & \multirow{4}{*}{3,33} \\
\hline & $\begin{array}{l}\text { a. Pencapaian metode berdasarkan SK, KD, } \\
\text { indikator, tujuan dan materi pembelajaran }\end{array}$ & 4 & \\
\hline & $\begin{array}{l}\text { b. Penetapan metode bervariasi dan } \\
\text { berpusat pada aktivitas siswa }\end{array}$ & 3 & \\
\hline & $\begin{array}{l}\text { c. Penetapan metode bersifat praktis dan } \\
\text { fungsional }\end{array}$ & 3 & \\
\hline \multirow[t]{4}{*}{5} & $\begin{array}{l}\text { Pengembangan } \\
\text { pembelajaran }\end{array}$ & & \multirow{4}{*}{3,00} \\
\hline & $\begin{array}{l}\text { a. Langkah-langkah pembelajaran sesuai } \\
\text { dengan metode yang ditetapkan }\end{array}$ & 3 & \\
\hline & $\begin{array}{l}\text { b. Langkah-langkah pembelajaran berurutan } \\
\text { sesuai dengan hirearki materi } \\
\text { pembelajaran }\end{array}$ & 3 & \\
\hline & $\begin{array}{l}\text { c. Langkah-langkah pembelajaran } \\
\text { memberikan pengalaman pembelajaran }\end{array}$ & 3 & \\
\hline \multirow[t]{4}{*}{6} & Penggunaan alat media dan sumber belajar & & \multirow{4}{*}{2,66} \\
\hline & $\begin{array}{l}\text { a. Relevan dengan SK, KD, indikator, tujuan } \\
\text { dan materi pembelajaran }\end{array}$ & 3 & \\
\hline & $\begin{array}{l}\text { b. Mudah dibuat, ekonomis, inovatif dan } \\
\text { realistic }\end{array}$ & 3 & \\
\hline & $\begin{array}{l}\text { c. Menunjang prinsip belajar berdsarkan } \\
\text { pengalaman (learning by doing) }\end{array}$ & 2 & \\
\hline \multirow[t]{2}{*}{7} & Pelaksanaan penilaian pembelajaran & & \multirow[b]{2}{*}{2,66} \\
\hline & $\begin{array}{l}\text { a. Penilaian pengukuran proses dan hasil } \\
\text { sesuai dengan } \mathrm{SK}, \mathrm{KD} \text {, indikator , tujuan } \\
\text { dan materi pembelajaran }\end{array}$ & 3 & \\
\hline
\end{tabular}




\begin{tabular}{|c|c|c|c|}
\hline \multirow{3}{*}{ No } & Aspek Deskriptor & Skor & Nilai \\
\hline & $\begin{array}{l}\text { b. Bentuk penilaian bervariasi (tes, tugas, } \\
\text { sikap, dan penilaian diri) }\end{array}$ & 2 & \\
\hline & $\begin{array}{l}\text { c. Mencantumkan kriteria keberhasilan } \\
\text { pencapaian kompetensi }\end{array}$ & 3 & \\
\hline \multirow[t]{4}{*}{8} & \multicolumn{2}{|l|}{ Kerapihan dan kebersihan RPP } & \multirow{4}{*}{3,33} \\
\hline & $\begin{array}{l}\text { a. Penggunaan kosakata dan struktur } \\
\text { kalimat yang efektif }\end{array}$ & 3 & \\
\hline & b. Penataan isi sistematis dan proporsional & 3 & \\
\hline & c. Tampilan umum bersih dan rapih & 4 & \\
\hline & Jumlah aspek & & 24,3 \\
\hline & Rata-rata & & 3,03 \\
\hline & $\%$ & & $\begin{array}{c}75,75 \\
\%\end{array}$ \\
\hline
\end{tabular}

Nilai APKG I $=\mathrm{x}$ (Rata-rata aspek deskriptor).

$x=\frac{3,66+3,00+2,66+3,33+3,00+2,66+2,66+3,33}{8}$

$$
=\frac{24,3}{8}=3,03
$$

Presentase $(\%)=\frac{\text { nilai yang diperoleh }}{\text { nilai maksimal }} \times 100 \%$

$=\frac{3,03}{4} \times 100 \%=\mathbf{7 5 , 7 5 \%}$

Untuk menafsirkan data tersebut, menggunakan kriteria sebagai berikut :

Kriteria Penilaian :

Skor 3,26-4,00 = Sangat Baik (SB)

Skor 2,51-3,25 = Baik

Skor 1,76-2,50 = Cukup

(B)

Skor 1,00-1,75 = Kurang

(K)

Berdasarkan Tabel 4.2 menunjukkan kemampuan pendidik dalam menyusun rencana pelaksanaan pembelajaran tergolong baik, hal ini karena dalam penilaian mencapai rata - rata 3,03 atau 75,75 \%. Target yang ditetapkan minimal rata - rata 3,03 atau 75,75 \% sudah tercapai.

\section{b. Siklus II}

Sebelum siklus II dilaksanakan, terlebih dahulu disusun Rencana Pelaksanaan Pembelajaran yang disesuaikan dengan hasil perbaikan pada siklus I. Tidak berbeda dengan siklus I, dalam pelaksanaan Siklus II juga terdiri dari dua kali tatap muka dengan SK dan KD yang sama sedangkan indikator yang hendak dicapai untuk kedua tatap muka berbeda yaitu sebagai berikut: 
Tabel 3. Hasil Penelitian Perencanaan Siklus II

\begin{tabular}{|c|c|c|c|}
\hline $\begin{array}{c}\text { Standar } \\
\text { Kompetensi }\end{array}$ & $\begin{array}{c}\text { Kompetensi } \\
\text { Dasar }\end{array}$ & Indikator & Waktu \\
\hline \multirow[t]{2}{*}{$\begin{array}{l}\text { Memahami } \\
\text { berbagai cara } \\
\text { gerak benda, } \\
\text { hubungannya } \\
\text { dengan energi } \\
\text { dan sumber } \\
\text { energi. }\end{array}$} & \multirow[t]{2}{*}{$\begin{array}{l}\text { Mendeskripsikan } \\
\text { hasil pengamatan } \\
\text { tentang pengaruh } \\
\text { energi panas, gerak, } \\
\text { dan bunyi dalam } \\
\text { kehidupan sehari- } \\
\text { hari }\end{array}$} & $\begin{array}{l}\text { Menyebutkan } \\
\text { macam-macam } \\
\text { sumber energi }\end{array}$ & $\begin{array}{l}\text { Pertemuan } \\
\text { ke }-1 \\
\text { Selasa, } \\
11 \\
\text { September } \\
2018\end{array}$ \\
\hline & & $\begin{array}{l}\text { Mengetahui } \\
\text { tujuan } \\
\text { kegunaan } \\
\text { sumber energi }\end{array}$ & $\begin{array}{l}\text { Pertemuan } \\
\text { ke }-2 \\
\text { Kamis, } \\
13 \\
\text { September } \\
2018\end{array}$ \\
\hline
\end{tabular}

Instrumen penelitian yang digunakan selama penelitian tindakan kelas meliputi :

1) Lembar penilaian rencana pelaksanaan pembelajaran;

2) Lembar observasi aktivitas pendidik;

3) Lembar observasi aktivitas peserta didik;

4) Membuat instrumen penilaian.

Sebelum pelaksanaan penelitian tindakan kelas, Rencana Pelaksanaan Pembelajaran yang telah disusun terlebih dahulu dinilai oleh observer dengan hasil sebagai berikut:

Tabel 4. Penilaian Penyusunan RPP Tindakan Siklus II

\begin{tabular}{|c|c|c|c|}
\hline No & Aspek deskriptor & Skor & Nilai \\
\hline \multirow[t]{4}{*}{1} & $\begin{array}{l}\text { Aspek Standar Kompetensi (SK), Kompensi } \\
\text { Dasar (KD) dan Indikator Keberhasilan } \\
\text { Kompetensi }\end{array}$ & & \multirow{4}{*}{4,00} \\
\hline & $\begin{array}{l}\text { a. Mencantumkan SK sesuai dengan mata } \\
\text { pelajaran yang diajarkan }\end{array}$ & 4 & \\
\hline & b. Mencantumkan satu KD berdasarkan SK & 4 & \\
\hline & $\begin{array}{l}\text { c. Merumuskan indikator berdsarkan KD } \\
\text { sesuai materi ajar }\end{array}$ & 4 & \\
\hline \multirow[t]{2}{*}{2} & $\begin{array}{l}\begin{array}{l}\text { Perumusan dan penetapan tujuan } \\
\text { pembelajaran }\end{array} \\
\end{array}$ & & \multirow{2}{*}{3,33} \\
\hline & $\begin{array}{l}\text { a. Tujuan tersusun berdasarkan SK, KD, } \\
\text { indikator percapaian kompetensi }\end{array}$ & 4 & \\
\hline
\end{tabular}




\begin{tabular}{|c|c|c|c|}
\hline No & Aspek deskriptor & Skor & Nilai \\
\hline & $\begin{array}{l}\text { b. Tujuan tesusun secara sistematis sesuai } \\
\text { dengan hirearki materi pembelajaran }\end{array}$ & 3 & \\
\hline & $\begin{array}{l}\text { c. Tujuan menggunakan kata-kata } \\
\text { operasional sesuai karakteristik mata } \\
\text { pelajaran }\end{array}$ & 3 & \\
\hline \multirow[t]{4}{*}{3} & Pengembangan materi pembelajaran & & \multirow{4}{*}{3,33} \\
\hline & $\begin{array}{l}\text { a. Materi berdasarkan SK, KD, Indikator, } \\
\text { tujuan dan materi pembelajaran }\end{array}$ & 4 & \\
\hline & $\begin{array}{l}\text { b. Materi sesuai dengan minat, } \\
\text { perkembangan anak dan kebutuhan } \\
\text { belajar anak }\end{array}$ & 3 & \\
\hline & $\begin{array}{l}\text { c. Materi sesuai karakteristik dan kebutuhan } \\
\text { lingkungan sekolah }\end{array}$ & 3 & \\
\hline \multirow[t]{4}{*}{4} & Penetapan metode pembelajaran & & \multirow{4}{*}{3,00} \\
\hline & $\begin{array}{l}\text { a. Pencapaian metode berdasarkan SK, KD, } \\
\text { indikator, tujuan dan materi pembelajaran }\end{array}$ & 3 & \\
\hline & $\begin{array}{l}\text { b. Penetapan metode bervariasi dan } \\
\text { berpusat pada aktivitas siswa }\end{array}$ & 3 & \\
\hline & $\begin{array}{l}\text { c. Penetapan metode bersifat praktis dan } \\
\text { fungsional }\end{array}$ & 3 & \\
\hline \multirow[t]{5}{*}{5} & $\begin{array}{l}\text { Pengembangan langkah-langkah } \\
\text { pembelajaran }\end{array}$ & & \multirow{5}{*}{3,33} \\
\hline & $\begin{array}{l}\text { a. Langkah-langkah pembelajaran sesuai } \\
\text { dengan metode yang ditetapkan }\end{array}$ & 4 & \\
\hline & $\begin{array}{l}\text { b. Langkah-langkah pembelajaran berurutan } \\
\text { sesuai dengan hirearki materi } \\
\text { pembelajaran }\end{array}$ & 3 & \\
\hline & $\begin{array}{l}\text { c. Langkah-langkah pembelajaran berurutan } \\
\text { sesuai dengan hirearki materi } \\
\text { pembelajaran }\end{array}$ & 3 & \\
\hline & $\begin{array}{l}\text { d. Langkah-langkah pembelajaran } \\
\text { memberikan pengalaman pembelajaran }\end{array}$ & 3 & \\
\hline \multirow[t]{4}{*}{6} & Penggunaan alat media dan sumber belajar & & \multirow{4}{*}{4,00} \\
\hline & $\begin{array}{l}\text { a. Relevan dengan SK, KD, indikator, tujuan } \\
\text { dan materi pembelajaran }\end{array}$ & 4 & \\
\hline & $\begin{array}{l}\text { b. Mudah dibuat, ekonomis, inovatif dan } \\
\text { realistic }\end{array}$ & 4 & \\
\hline & $\begin{array}{l}\text { c. Menunjang prinsip belajar berdsarkan } \\
\text { pengalaman (learning by doing) }\end{array}$ & 4 & \\
\hline \multirow[t]{2}{*}{7} & Pelaksanaan penilaian pembelajaran & & \multirow[b]{2}{*}{3.00} \\
\hline & $\begin{array}{l}\text { a. Penilaian pengukuran proses dan hasil } \\
\text { sesuai dengan SK, KD, indikator , tujuan } \\
\text { dan materi pembelajaran }\end{array}$ & 3 & \\
\hline
\end{tabular}




\begin{tabular}{|c|c|c|c|}
\hline \multirow[t]{3}{*}{ No } & Aspek deskriptor & \multirow{2}{*}{\begin{tabular}{|r} 
Skor \\
3
\end{tabular}} & \multirow[t]{3}{*}{ Nilai } \\
\hline & $\begin{array}{l}\text { b. Bentuk penilaian bervariasi (tes, tugas, } \\
\text { sikap, dan penilaian diri) }\end{array}$ & & \\
\hline & $\begin{array}{l}\text { c. Mencantumkan kriteria keberhasilan } \\
\text { pencapaian kompetensi }\end{array}$ & 3 & \\
\hline \multirow[t]{4}{*}{8} & Kerapihan dan kebersihan RPP & \multirow[b]{2}{*}{3} & \multirow{4}{*}{3,33} \\
\hline & $\begin{array}{l}\text { a. Penggunaan kosakata dan struktur } \\
\text { kalimat yang efektif }\end{array}$ & & \\
\hline & b. Penataan isi sistematis dan proporsional & 3 & \\
\hline & c. Tampilan umum bersih dan rapih & 4 & \\
\hline & Jumlah aspek & & 27,32 \\
\hline & Rata-rata & & 3,41 \\
\hline & $\%$ & & 85,2 \\
\hline
\end{tabular}

Nilai APKG II = x (Rata-rāta aspek deskriptor).

$x=\frac{4,0 \underline{0}+3,33+3,33+3,00+3,33+4,00+3,00+3,33}{8}$

$$
=\frac{27,3}{8}=3,41
$$

Presentase $(\%)=\frac{\text { nilai yang diperoleh }}{\text { nilai maksimal }} \times 100 \%$

$$
=\frac{3,41}{4} \times 100 \%=\mathbf{8 5}, \mathbf{2 5} \%
$$

Untuk menafsirkan data tersebut, menggunakan kriteria sebagai berikut :

\section{Kriteria Penilaian :}

Skor 3,26-4,00 = Sangat Baik (SB)

Skor 2,51-3,25 = Baik Skor 1,76-2,50 = Cukup

Skor 1,00-1,75 = Kurang

Berdasarkan Tabel menunjukkan kemampuan pendidik dalam menyusun Rencana pelaksanaan pembelajaran tergolong sangat baik karena mencapai rata - rata $3,41(85,25 \%)$ Target yang ditetapkan minimal rata - rata $75 \%$ sudah tercapai

\section{Pelaksanaan}

\section{a. Siklus 1}

Pelaksanaan penelitian tindakan kelas siklus I terdiri dari 2 kali pertemuan dan dilaksanakan sesuai dengan waktu yang telah direncanakan, yakni pada tanggal 03 September 2018 sampai dengan 10 September 2018. Dalam pelaksanaan pembelajaran siklus I terdiri dari kegiatan awal, kegiatan inti dan kegiatan akhir.

Tahap awal pembelajaran, guru mengucapkan salam dan menyapa peserta didik kemudian guru bersama peserta didik berdoa. Langkah selanjutnya sebagai kegiatan apersepsi, guru mengecek kehadiran peserta didik, mempersiapkan bahan ajar dan alat praga. 


\section{Madrosatuna: Jurnal Pendidikan Guru}

Madrasah Ibtidaiyah

Volume 1 Nomor 2 (2018) 1-15

http://jurnal.iailm.ac.id/index.php/madrosatuna

\section{b. Siklus 2}

Pelaksanaan penelitian tindakan kelas siklus II terdiri dari 2 kali pertemuan dan dilaksanakan sesuai dengan waktu yang telah direncanakan, yakni pada tanggal 11 September 2018 sampai dengan 15 September 2018. Dalam pelaksanaan pembelajaran siklus II terdiri dari kegiatan awal, kegiatan inti dan kegiatan akhir.

Tahap awal pembelajaran, guru mengucapkan salam dan menyapa peserta didik kemudian guru bersama peserta didik berdoa. Langkah selanjutnya sebagai kegiatan apersepsi, guru mengecek kehadiran peserta didik ,mempersiapkan bahan ajar dan alat peraga, serta mengingat kembali materi yang telah dipelajari sebelumnya.

\section{Hasil Belajar}

\section{a. Siklus 1}

Pada akhir pembelajaran diadakan evaluasi kepada peserta didik. Evaluasi ini dalam bentuk tes secara tertulis.

Tabel 5. Hasil Belajar Peserta Didik Pada Penelitian Tindakan Siklus I

\begin{tabular}{|c|c|c|c|c|c|c|}
\hline \multirow[t]{2}{*}{ NO } & \multirow{2}{*}{ NAMA } & \multirow{2}{*}{ KKM } & \multirow{2}{*}{$\begin{array}{l}\text { Pra } \\
\text { SIKLUS }\end{array}$} & \multirow{2}{*}{ NILAI } & \multicolumn{2}{|c|}{ KETERANGAN } \\
\hline & & & & & $\mathrm{T}$ & BT \\
\hline 1 & ABIL ATH THORIQ & 65 & 60 & 65 & $\sqrt{ }$ & \\
\hline 2 & $\begin{array}{l}\text { ADILA NUR FAZRIA } \\
\text { SUPRIATNA }\end{array}$ & 65 & 70 & 75 & $\sqrt{ }$ & \\
\hline 3 & AEP SAEPUL RAMDANI & 65 & 50 & 60 & & $\sqrt{ }$ \\
\hline 4 & ANDINI APRILIANI & 65 & 50 & 55 & & $\sqrt{ }$ \\
\hline 5 & $\begin{array}{l}\text { ANNISA AIRIN } \\
\text { NURIKHSANI }\end{array}$ & 65 & 70 & 75 & $\sqrt{ }$ & \\
\hline 6 & ARIZA FADLUROHMAN & 65 & 45 & 55 & & $\sqrt{ }$ \\
\hline 7 & $\begin{array}{l}\text { DEDEN RAHMAT } \\
\text { SAPUTRA }\end{array}$ & 65 & 65 & 70 & $\sqrt{ }$ & \\
\hline 8 & DIKA NUGRAHA & 65 & 40 & 50 & & $\sqrt{ }$ \\
\hline 9 & DE SALSA ASMARANI & 65 & 70 & 75 & $\sqrt{ }$ & \\
\hline 10 & FARHAN FADILAH & 65 & 30 & 50 & & $\sqrt{ }$ \\
\hline 11 & FIKRI RAMDANI & 65 & 50 & 60 & & $\sqrt{ }$ \\
\hline 12 & GILANG RAMADHAN & 65 & 45 & 55 & & $\sqrt{ }$ \\
\hline 13 & ILAH NUR FADILAH & 65 & 55 & 60 & & $\sqrt{ }$ \\
\hline 14 & LENI SYAMROTUL AEN & 65 & 65 & 70 & $\sqrt{ }$ & \\
\hline 15 & MAYA AULIA & 65 & 50 & 60 & & $\sqrt{ }$ \\
\hline 16 & MUHAMAD RIDWAN & 65 & 30 & 50 & & $\sqrt{ }$ \\
\hline 17 & $\begin{array}{l}\text { RAIHANA NAJHIFA } \\
\text { RUHIYAT }\end{array}$ & 65 & 50 & 55 & & $\sqrt{ }$ \\
\hline 18 & $\begin{array}{l}\text { NAKESYA AMAIRA } \\
\text { GABRIELA }\end{array}$ & 65 & 65 & 70 & $\sqrt{ }$ & \\
\hline 19 & NAJIYA SITI SOLIHAH & 65 & 60 & 75 & $\sqrt{ }$ & \\
\hline
\end{tabular}


Madrosatuna: Jurnal Pendidikan Guru

Madrasah Ibtidaiyah

Volume 1 Nomor 2 (2018) 1-15

http://jurnal.iailm.ac.id/index.php/madrosatuna

\begin{tabular}{|c|c|c|c|c|c|c|}
\hline \multirow{2}{*}{ NO } & \multirow{2}{*}{ NAMA } & \multirow{2}{*}{ KKM } & \multirow{2}{*}{$\begin{array}{l}\text { Pra } \\
\text { SIKLUS }\end{array}$} & \multirow{2}{*}{ NILAI } & \multicolumn{2}{|c|}{ KETERANGAN } \\
\hline & & & & & $\mathrm{T}$ & BT \\
\hline 20 & NAUFAL NURHIDAYAH & 65 & 30 & 45 & & $\sqrt{ }$ \\
\hline 21 & RINA & 65 & 60 & 70 & $\sqrt{ }$ & \\
\hline 22 & SAHRUL GINANJAR & 65 & 50 & 65 & $\sqrt{ }$ & \\
\hline 23 & SINTA NURAENI & 65 & 50 & 60 & & $\sqrt{ }$ \\
\hline 24 & SITI SALMA MAULIDA & 65 & 55 & 60 & & $\sqrt{ }$ \\
\hline 25 & SRI DEWI NURHAYATI & 65 & 65 & 70 & $\sqrt{ }$ & \\
\hline 26 & $\begin{array}{l}\text { SULISTIANI FAUZIYAH } \\
\text { HAMDANI }\end{array}$ & 65 & 70 & 75 & $\sqrt{ }$ & \\
\hline \multicolumn{4}{|c|}{ NILAI TERTINGGI } & 75 & & \\
\hline \multicolumn{4}{|c|}{ NILAI TERENDAH } & 45 & & \\
\hline \multicolumn{4}{|c|}{ JUMLAH } & 1.630 & & \\
\hline \multicolumn{4}{|c|}{ RATA - RATA } & 62,69 & & \\
\hline \multicolumn{4}{|c|}{ \% KETUNTASAN } & $46,18 \%$ & & \\
\hline
\end{tabular}

$\%$ Ketuntasan $=\frac{\text { jumlah peserta didik yang tuntas }}{26} \times 100 \%$

Keterangan :

$\mathrm{T}=$ Tuntas

BT $=$ Belum Tuntas

Dari analisis terhadap hasil belajar peserta didik setelah pelaksanaan penelitian tindakan kelas siklus I, diperoleh rata - rata hasil belajar peserta didik mencapai nilai 62,69. Jumlah peserta didik yang telah mencapai ketuntasan belajar baru mencapai 12 orang atau 46,18\% dari jumlah seluruh peserta didik. Target pencapaian nilai ditetapkan rata - rata minimal 65,00 dan ketuntasan belajar mencapai $100 \%$ belum tercapai. Hal ini menunjukkan bahwa penguasaan peserta didik terhadap materi pelajaran masih rendah.

\section{b. Siklus II}

Pada akhir pembelajaran diadakan evaluasi kepada peserta didik. Evaluasi tersebut dilakukan secara tertulis. Hasil dari penilaian pada siklus II adalah sebagai berikut :

Tabel 6. Hasil Belajar Peserta Didik Pada Penelitian Tindakan Siklus II

\begin{tabular}{|c|l|c|c|c|c|}
\hline \multirow{2}{*}{ No } & \multicolumn{1}{|c|}{ NAMA } & \multirow{2}{*}{ KKM } & \multirow{2}{*}{ NILAI } & \multicolumn{2}{|c|}{ KETERANGAN } \\
\cline { 4 - 6 } & & & & T & BT \\
\hline 1 & ABIL ATH THORIQ & 65 & 85 & $\sqrt{ }$ & \\
\hline 2 & $\begin{array}{l}\text { ADILA NUR FAZRIA } \\
\text { SUPRIATNA }\end{array}$ & 65 & 90 & $\sqrt{ }$ & \\
\hline 3 & AEP SAEPUL RAMDANI & 65 & 70 & $\sqrt{ }$ & \\
\hline 4 & ANDINI APRILIANI & 65 & 75 & $\sqrt{ }$ & \\
\hline 5 & ANNISA AIRIN NURIKHSANI & 65 & 100 & $\sqrt{ }$ & \\
\hline 6 & ARIZA FADLUROHMAN & 65 & 70 & $\sqrt{ }$ & \\
\hline
\end{tabular}




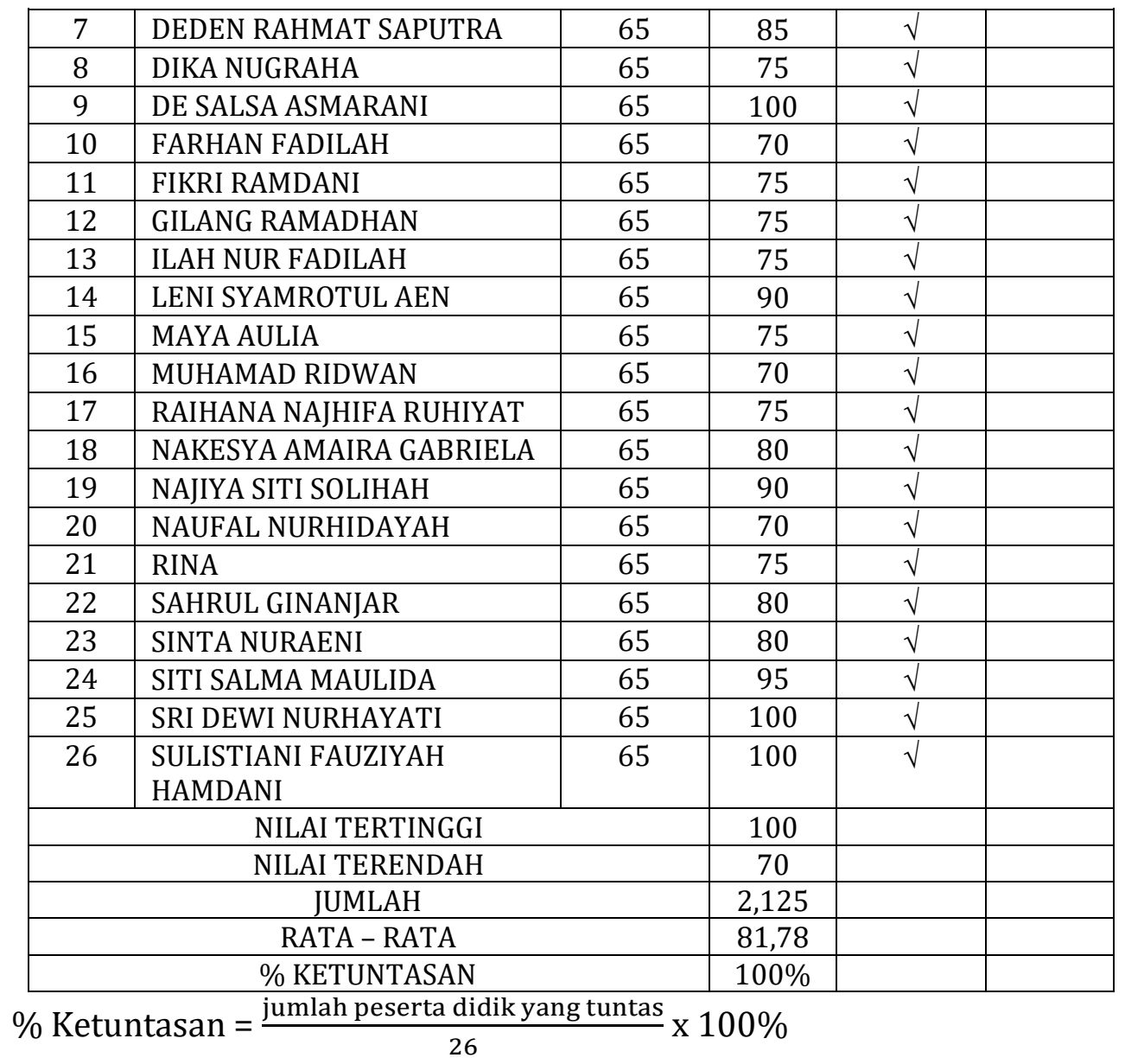

Keterangan :

$\mathrm{T}=$ Tuntas

$\mathrm{BT}=$ Belum Tuntas

Dari analisis terhadap hasil belajar peserta didik setelah pelaksanaan penelitian tindakan kelas siklus II, diperoleh nilai rata - rata hasil belajar sebesar 81,78 dengan nilai tertinggi 100 dan nilai terendah mencapai 70. Peserta didik yang telah mencapai ketuntasan belajar mencapai 26 orang atau $100 \%$ dari jumlah seluruh peserta didik. Hal ini menunjukkan bahwa target pencapaian minimal telah tercapai dengan sangat baik.

\section{Pembahasan}

Penilaian hasil belajar peserta didik berupa tes formatif yang dilakukan pada siklus I sampai II. Rekapitulasi hasil belajar peserta didik kelas III di MIS Hegarmanah Panjalu, dapat dilihat pada tabel berikut :

Tabel 7. Hasil Belajar Peserta Didik Pra Siklus, Siklus I dan Siklus II 


\begin{tabular}{|c|c|c|c|c|}
\hline \multirow[b]{2}{*}{ No. } & \multirow[b]{2}{*}{ Nama Peserta Didik } & \multicolumn{3}{|c|}{ Nilai } \\
\hline & & $\begin{array}{c}\text { Pra } \\
\text { Siklus }\end{array}$ & Siklus I & $\begin{array}{c}\text { Siklus } \\
\text { II }\end{array}$ \\
\hline 1 & ABIL ATH THORIQ & 60 & 65 & 85 \\
\hline 2 & ADILA NUR FAZRIA SUPRIATNA & 70 & 75 & 90 \\
\hline 3 & AEP SAEPUL RAMDANI & 50 & 60 & 70 \\
\hline 4 & ANDINI APRILIANI & 50 & 55 & 75 \\
\hline 5 & ANNISA AIRIN NURIKHSANI & 70 & 75 & 100 \\
\hline 6 & ARIZA FADLUROHMAN & 45 & 55 & 70 \\
\hline 7 & DEDEN RAHMAT SAPUTRA & 65 & 70 & 85 \\
\hline 8 & DIKA NUGRAHA & 40 & 50 & 75 \\
\hline 9 & DE SALSA ASMARANI & 70 & 75 & 100 \\
\hline 10 & FARHAN FADILAH & 30 & 50 & 70 \\
\hline 11 & FIKRI RAMDANI & 50 & 60 & 75 \\
\hline 12 & GILANG RAMADHAN & 45 & 55 & 75 \\
\hline 13 & ILAH NUR FADILAH & 55 & 60 & 75 \\
\hline 14 & LENI SYAMROTUL AEN & 65 & 70 & 90 \\
\hline 15 & MAYA AULIA & 50 & 60 & 75 \\
\hline 16 & MUHAMAD RIDWAN & 30 & 50 & 70 \\
\hline 17 & RAIHANA NAJHIFA RUHIYAT & 50 & 55 & 75 \\
\hline 18 & NAKESYA AMAIRA GABRIELA & 65 & 70 & 80 \\
\hline 19 & NAJIYA SITI SOLIHAH & 60 & 75 & 90 \\
\hline 20 & NAUFAL NURHIDAYAH & 30 & 45 & 70 \\
\hline 21 & RINA & 60 & 70 & 75 \\
\hline 22 & SAHRUL GINANJAR & 50 & 65 & 80 \\
\hline 23 & SINTA NURAENI & 50 & 60 & 80 \\
\hline 24 & SITI SALMA MAULIDA & 55 & 60 & 95 \\
\hline 25 & SRI DEWI NURHAYATI & 65 & 70 & 100 \\
\hline 26 & SULISTIANI FAUZIYAH HAMDANI & 70 & 75 & 100 \\
\hline & NILAI TERTINGGI & 70 & 75 & 100 \\
\hline & NILAI TERENDAH & 30 & 45 & 70 \\
\hline & JUMLAH & 1.400 & 1.630 & 2.125 \\
\hline & RATA - RATA & 53,84 & 62,69 & 81,78 \\
\hline & ENTASE KETUNTASAN (\%) & $30,76 \%$ & $46,18 \%$ & $100 \%$ \\
\hline
\end{tabular}

Berdasarkan tabel 4.14, hasil belajar peserta didik dalam pembelajaran dengan menerapkan model pembelajaran kooperatif tipe STAD (student team achievement divisions) mengalami peningkatan dalam hasil belajar . Pada siklus I nilai tertinggi memperoleh 75 dan nilai terendah mencapai 45 dengan presentase ketuntasan mencapai 46,18\%. Pada siklus II nilai tertinggi mencapai 100 dan terendah mencapai 70 dengan presentase ketuntasan 100\%. Hal ini menunjukkan adanya perubahan dan peningkatan hasil belajar peserta didik dari siklus I ke siklus II. 


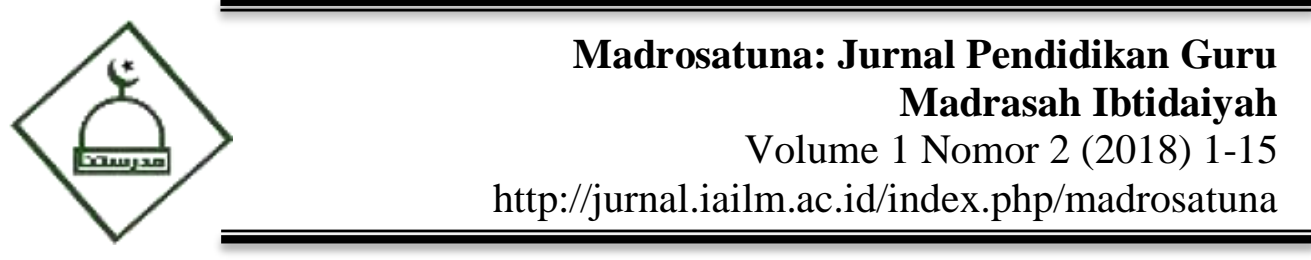

\section{Simpulan}

Setelah Melakukan Penelitian mengenai "Model Kooperatif Tipe Student Teams Achievement Division untuk meningkatkan hasil belajar peserta didik dalam operasi hitung perkalian di Kelas III SDN 8 Panjalu maka dapat disimpulkan sebagai berikut:

\section{Perencanaan Pembelajaran}

Dengan menggunakan Model Kooperatif Tipe Student Teams Achievement Division untuk meningkatkan hasil belajar peserta didik kelas III di MIS Hegarmanah kecamatan Panjalu kabupaten Ciamis dapat disusun dengan berpedoman pada standar kompetensi, kompetensi dasar dan indikator pada materi pokok Energi serta karakteristik model pembelajaran kooperatif tipe STAD (Student Team Achievement Division). Selain itu Rencana Pelaksanaan Pembelajaran (RPP) disusun dengan memperhatikan sumber dan media pembelajaran. Berdasarkan hasil observasi terdapat peningkatan yang cukup signifikan pada kinerja guru dalam merencanakan pembelajaran. Jika pada siklus I mencapai 75,75\%, maka pada siklus II meningkat menjadi $85,25 \%$.

\section{Pelaksanaan Pembelajaran}

Dengan menggunakan model pembelajaran kooperatif tipe STAD (Student Team Achievement Division) dapat meningkatkan hasil belajar peserta didik dan model ini membuat pembelajaran lebih jelas dan konkret. Hal tersebut ditunjukan dengan peserta didik lebih mudah dalam memahami apa yang dipelajari, peserta didik lebih tertarik dengan pelajaran, peserta didik lebih aktif dalam proses pembelajaran, serta mampu berinteraksi dengan baik antar sesama peserta didik. Selain itu berdasarkan hasil observasi menunjukan bahwa terdapat peningkatan yang cukup signifikan pada kinerja guru dalam melaksanakan pembelajaran setelah diterapkannya model pembelajaran kooperatif tipe STAD (Student Team Achievement Division). Jika pada siklus I persentasenya mencapai 69,25\%, maka pada siklus II persentasenya meningkat menjadi $85,5 \%$.

\section{Kemampuan Hasil Belajar Peserta Didik}

Pembelajaran dengan model pembelajaran kooperatif tipe STAD (Student Team Achievement Division) di kelas III MIS Hegarmanah pada mata pelajaran IPA dapat dilaksanakan dengan efektif dan dapat meningkatkan hasil belajar peserta didik. Hai ini berdasarkan hasil observasi bahwa nilai evaluasi akhir peserta didik mengalami peningkatan yang cukup signifikan yaitu pada pembelajaran siklus I rata-rata kelas 65 ataun persentase mencapai $65 \%$, dan pada pembelajaran siklus II rata-rata kelas eningkat menjadi 75 atau persentasenya mencapai $75 \%$.

\section{Referensi}

Nurhamzah, Penelitian Tindakan Kelas, Bandung: CV Wahana Karya Grafika

Ekawarna, (2013), Penelitian Tindakan Kelas, Jakarta: GP Press Group

Priyono, dan Titik Sayekti, (2008), Ilmu Pengetahuan Alam Untuk SD dan MI 
Kelas III, Bandung: PT Karsa Mandiri Persada

Sudjana, Nana, (2013), Penilaian Hasil Proses Belajar Mengajar, Bandung: PT Remaja Rosdakarya

Nurhamzah, (2012), Pembelajaran Matematika, Bandung: CV Wahana Karya Grafika

Hayati, Tuti, (2014), Evaluasi Pembelajaran, Bandung: Insan Mandiri

Putra, Rizema, (2012),Desain Belajar Mengajar Kreatif Berbasis Sains, Jogjakarta:Diva Press

Sukiyadi, Didi dkk, (2006), Kurikulum dan Pembelajaran, Bandung: UPI Press 